\title{
Influence of surface geometry and structure after non-conventional methods of parting on the following milling operations
}

Anna Mičietová, Miroslav Neslušan, Mária Čilliková

University of Žilina, Faculty of Mechanical Engineering, Department of Machining and Manufacturing Engineering, Univerzitná 1, 010 26, Slovak Republic, anna.micietova@ fstroj.uniza.sk

This investigates influence of non-conventional methods of parting of steel 11373.0 on structure transformations and associated geometry. Wire electro discharge machining (WEDM), plasma and laser cutting methods were used and compared as competitive methods from the point of view of structure transformations, associated geometry of a part and associated cutting forced produced during the following milling process. Results of this study indicate that significant differences can be found among the mentioned technology since the different thermal load of machined surface. Furthermore, structure and geometry alteration occurring after parting strongly affect cutting forces during the following milling operations.

Keywords: laser, plasma, WEDM, milling, cutting forces

\section{Acknowledgment}

This project is solved under the financial support of VEGA agency (project n. 1/0097/12 and n. 1/0223/11) and KEGA agency (project n. 023TUKE-4/2012 and 031ŽU-4/2011).

\section{References}

[1] FABIAN, S., STRAKA, L. (2006). Kvantifikace funkčních závislostí parametru kvality na technologických parametrech při elektroerozivním řezání kovu. In: Strojírenská technologie, XI/2006, č. 2, pp. 21 - 24.

[2] GANEV, N., ZEMAN P., KOLAŘÍK, K.., BAAKALOVÁ, T. (2007). Residual Stresses Distribution in Surface Layer after Milling of Steel. In: Manufacturing Technology, VII/ 2007, pp. 10.

[3] LUKOVICS, I., MALACHOVÁ, M. (2007). Use of Laser in Engineering. In: Manufacturing Technology, VII/ 2007, pp. 26 - 317.

[4] MADL, J., JERSAK, J., HOLEŠOVSKY, F., aj. (2003). Jakost obráběných povrchu, pp. 1791. Vyd. Ústi nad Labem, UJEP.

[5] MANAS, D. (2009). Tepelné ovlivněni oceli při různých způsobech dělení. In: Strojírenská technologie, Časopis pro vedu, výzkum a výrobu, prosinec 2009, roč. XIV., č. 4, pp. 26 - 33.

[6] MAŇKOVÁ, I. (2000). Progresívne technológie, pp. 275. Vienala - vydavatel'stvo, Košice.

[7] MIČIETOVÁ, A., ČILLIKOVÁ, M., SALAJ, J. (2009). Influence of some selected factors on surface quality when cutting by plasma and laser beam. In: Journal of Machine Manufacturing, The Scientific Society for Mechanical Engineering, Volume XLIX, Issue E3-E5, INDEX: 25344, pp. 104 - 106, Hungary.

[8] MIČIETOVÁ, A., NESLUŠAN, M., ČILLIKOVÁ, M. (2013).Residual stresses after thermal methods parting. In: Machines Technologies Materials, international virtual journal, YEAR Vll Issue 2/2013, pp. 50 - 52.

[9] SKOČOVSKÝ, P. A KOL. (2006). Náuka o materiáli pre odbory strojnícke, pp. 51 - 78. EDIS - vydavatel'stvo ŽU, Žilina.

[10] TREIBER, H. (1990). Der Laser in der industriellen Fertigungstechnik. Hoppenstedt Technik Tabellen Verlag, Darmstadt.

[11] ZETEL, M., CESAKOVA, I., SAMKOVA, M., SOUKUP, O. (2011). Obrábění tepelně zpracovaných ploch laserem. In: Strojírenská technologie, roč. XVI/2011, č. 5, pp. 43 - 53. 